\title{
Sales Promotion Communication as Social Processes and Schematic Structures
}

\author{
Ming Cheung*
}

Department of Media and Communication, City University of Hong Kong, China

\begin{abstract}
The genre of sales promotion communication can be perceived as social processes; they are apt to be dynamic and evolving. The genre can be realized through socially recognized forms of texts; these forms arise from recurrent social situations and gradually become conventionalized and typified responses to similar situations. Each form is realized through a schematic structure, which refers to the organization of semantic units in a text. This study aims at discussing the development of a move scheme for analyzing the sales genre, based on the analysis of a real-life corpus instead of the subjective evaluation of one or a few discrete texts. To validate the move scheme put forward by the author, five specialist informants who on average had been working in the field of promotional writing and editing for ten years were consulted for their expert opinions and comments. Through analyzing the schematic structures, we can gain an understanding of how users of a sales genre contribute to the shaping of our views and knowledge of the world. The move scheme could form part of the learning materials for any courses or textbooks on the writing of sales promotion discourse.
\end{abstract}

Keywords: Sales promotion communication, sales genre, social process, schematic structure, move scheme, specialist informants.

\section{INTRODUCTION}

We live in a world of commerce, in which goods are sold and services are provided. Persuasive messages have long played a significant role in the process of buying and selling, from word of mouth in the past to marketing campaigns of the modern era. If it is agreed that persuasive messages are a major medium through which companies convey information about their brands, that they create a catalyst effect in boosting sales volume, that they have consistently affected our buying decisions as consumers, that they enhance crosscultural exchange, and that they contribute to modern civilization, then the investigation of persuasive messages in relation to business merits attention. This study aims at introducing a move scheme for analyzing sales promotion communication. Specifically, the scheme is derived from an analysis of 160 sales letters (80 prints and 80 emails) randomly selected from a database of 10,972 sales letters collected from 36 categories of recipients in Hong Kong over a six-month period. It has also been validated by five specialist informants working in the field of sales promotion communication.

This article will first discuss the concept of genre as social processes and as schematic structures. It will then delimit the notion of move and introduce the move scheme, with each move and step explained and illustrated with extracts taken from the corpus of 160 sales letters. It will end with a concluding remark on its contribution to the area of sales genre through the development of the move scheme based on the analysis of a real-life corpus instead of the subjective evaluation of one or a few discrete texts. Throughout

*Address correspondence to this author at the Department of Media and Communication, City University of Hong Kong, China;

E-mail: ming.cheung@cityu.edu.hk the article, the terms makers and viewers instead of authors and readers are used. Given that the persuasive messages in a sales letter might be encoded and decoded through text, graphics, images, new media, or a combination of these, using the terms authors and readers would be too restrictive in this research context. Here, makers refer to those people who are involved in the production of the letters, such as marketers, authors, and designers, while viewers refer to those who receive and view the sales letters, and they are the potential consumers of a product or service.

\section{Genre as Social Processes}

What constitutes and characterizes a particular genre? Over the years, many attempts have been made by scholars to define the notion. Dudley-Evans [1] defines genre as "a typified socially recognized form that is used in typified social circumstances." Purves [2] states, "Convention and need dictate the occasions for writing or reading and the functions of discourse appropriate to those occasions." Bhatia [3] adds,

Genres are products of an understanding or a prior knowledge of disciplinary or institutional conventions, which are responsible for regulating generic constructs, giving them an identity and internal ordering.

An example of a genre based on their interpretations is a diagnosis report written in the Companies Registry of Hong Kong for corporate complaints. The following information comes from the author's experience of working in the Registry some years ago. A corporation first submitted its complaint letters, usually via a solicitor firm or a company secretarial firm, to the Registry to put forward its queries or disagreements against a potential mischief done by another corporation. The complaint letters were documents relating to a recognized legal transaction, namely the pointing out of ir- 
regularities in business affairs and calling for response and action, in order to safeguard the benefit or position of individual corporations. All the complaint letters went through a series of steps upon receipt: information of the involved corporations was retrieved from the Registry's database; each letter was screened to determine whether a new case file should be opened and what type of complaint was being made; a diagnosis report was written by a companies registration officer with reference to the Companies Ordinance, and this report would then be forwarded to the Registry's legal officer for further action. In the process of preparing the diagnosis report, the companies registration officer would study the previous records of the involved corporations, analyze the nature of the present complaint, spot any potential deviations in accordance with the Companies Ordinance, and seek clarification from the complainant if necessary. The ultimate goal of the whole process was to resolve the conflict between the involved corporations.

Both the companies registration officer and the legal officer in the above example were members of the same social group, that is, a section handling legal cases in the Registry. They shared specific social relations and purposes. According to Kress [4], members of a social group can recognize genres common to the group, and it is through these genres that they acquire status and social effectiveness. The two officers would certainly have a similar expectation of what a diagnosis report was and be able to recognize the report as a genre. That means they belonged to the same "discourse community" [5], members of which will share a set of common public goals, mechanisms of intercommunication and feedback, repertoires of genres and specific lexis, and relevant discoursal expertise [5]. The above scenario reveals that genres are socially determined, as noted by Bazerman [6]:

A genre is a social construct that regularizes communication, interaction, and relations. Thus the formal features that are shared by the corpus of texts in a genre and by which we usually recognize a text's inclusion in a genre, are the linguistic/symbolic solution to a problem in social interaction.

In other words, the linguistic or symbolic choices available to a maker are determined by the genre to which a text belongs, and the "generic choices" [4] are then determined by the social situation in which the genre emerges. In the case of a sales letter, the field centers on marketing discourse, on promoting a brand, product, or service. The tenor of discourse is asymmetrical; the maker is responsible for pleasing the viewer and for persuading him or her to purchase a product or service. It is the viewer who holds the decision power of whether the social action of persuasion put forward by the maker will lead to a positive or favorable response. The mode of discourse is written; the function of the letter is to bring information of the brand, product, or service to the attention of the viewer, who hopefully, will become a customer.

The discussion so far also illustrates that "genres are social processes" [7]. The communicative purpose and the social function characterize "a class of texts" [8], "a class of discourses" [9], or "a class of communicative events" [5] with similar formal features into a genre. The sales letters are unsolicited appeals, designed to promote products and serv- ices to the general public as individualized customers. The letters carry with themselves a long-term goal of building up and maintaining goodwill of individual companies. The agentive or societal roles have the marketing officers as makers and members of the targeted customer segments as viewers. An unequal status relationship, being viewercentered, is deliberately set up by the makers. The maker may make use of a conversational and ellipted style of language to create a tone that sounds informal, engaging, intimate and causal. Thus, the social distance can be minimal to facilitate more interaction between the maker and the viewer. Non-specialist language is used. Taking up a purposive role to promote, it is informative and persuasive in outlining attractions, and directive and performative in urging immediate purchasing actions.

The features associated with texts help characterize a genre and at the same time, constrain what a genre should be, including but not limited to schematic structure, content and style of communicating meanings [5]. Nowadays, sales letters are still one of the major vehicles through which companies promote their brands, products, or services to their potential customers. They are seen and taught as a highly "standardized, ritual or even formulaic" genre [10], as reflected in the business communication textbooks [11-13]. Almost all books on sales letter writing discuss the discourse strategies in an AIDA model, which stands for Attention, Interest, Desire, and Action. A sales letter will first capture the viewer's attention with an interesting opener which relates directly or indirectly to the product or service being offered. The letter will then attempt to arouse the viewer's interest in the product or service and to create a desire in the viewer to own the product or service. The letter will lastly convince the viewer to act on that desire through a purchase, which is the ultimate goal of the sale.

The standardization in written discourse genres emerges from reciprocity between generic conventions and responses to situations. Kress [4] says,

I regard social occasions as involving complex social structuring which brings together specific combinations of "generic choices". Because of the regularity and frequency of these social occasions and therefore of the combinations of generic choices, forms of texts emerge... These I call genres.

Devitt [14] also remarks on this reciprocity, "Genre and situation are so linked as to be inseparable, but it is genre that determines situation as well as situation that determines genre". Indeed, it is possible to produce a text in imitation of similar texts. For example, students studying business communication at the author's university are asked to produce a sales letter, as one of their course assignments, to promote a product or service for a business simulation activity. The recipients of their letters are not real, but imagined. The letter serves to help them, as apprentices, learn the structure, content, and style of the genre. If generic conventions and predictable responses to situations do not exist, it will simply be impossible for the imitation of a genre to occur.

\section{Genre as Schematic Structures}

As described in the above section, genres are social processes; they define their users' social groups and help maintain the coherence among members of each group. The 
members, in turn, can recognize the genres and help preserve and control them. Due to the differing social occasions in which the genres emerge, each genre carries a distinctive communicative purpose and social function. Swales [5] depicts communicative purpose as a "privileged criterion" in identifying a genre and in keeping the scope of a genre "narrowly focused on comparable rhetorical action". The descriptions above emphasize the communicative functions of a genre on the one hand, and consider a genre as socially recognized forms of texts on the other. These forms arise from recurrent social situations and gradually become conventionalized and typified responses to similar situations. Each form is realized through a schematic structure, which refers to the organization of semantic units in a text [5]. Each semantic unit constitutes a move, which is a "rhetorical device" or a "rhetorical step" [15] for text analysis. According to Vergaro [10], analyzing the move structure of a text means "assigning a pragmatic function to a stretch of language and building the schematic structure through which its communicative purpose is achieved".

Genre analysis, as an approach to text analysis, is concerned with analyzing the structure and organization of information typical and conventional of genre-specific texts. It investigates the relationships between the communicative processes, the viewer-maker interaction, and the textual features of genre-specific texts; in particular, it investigates how the former two are represented through the latter. Analyzing genre-specific texts would provide a channel for us to understand the conventions of writing and the rhetorical patterns emerged for a genre. Through these conventions and patterns, we can gain an understanding of how users of a genre contribute to the shaping of our views and knowledge of the world.

\section{MATERIALS AND METHODOLOGY}

\section{Move Defined}

In order to achieve the rhetorical goal of persuasion, the maker of a sales letter may employ a number of strategies by, for example, describing the product as a solution to the customer's current problem, highlighting its benefits with supporting facts and evidence, or sharing a successful case of an existing user of the product. These strategies are assumed to be bringing to viewers of the letters some new or unexpected information, so that a company can better differentiate its offer from that of its competitors. The rhetorical strategies are realized by information units or a combination of them, which are often referred to as moves by many genre analysts. Mauranen [16] suggests a definition of the rhetorical move,

Rhetorical moves are functional units of text which participate in presenting the writer's claim in such a way as to increase the reader's acceptance of the claim. Rhetorical moves thus contribute to the writer's rhetorical strategy.

Upton and Connor [17] describe moves as semantic/functional units of texts which can be identified through their communicative purposes and through the linguistic boundaries typical of the moves. Bhatia [18] defines moves as "rhetorical instruments that realise a sub-set of specific communicative purposes associated with a genre"; recur- rence of particular moves and typicality of their appearance in genre-specific texts enable viewers to recognize these texts as exemplars of the same genre [5]. Moves, if viewed as such, work on coherence rather than isolation in a text. In this study, a move is defined as a meaningful unit related to the communicative purpose of a social activity and contributing to the overall strategy of a text in relation to its context of situation. The moves serve to represent the social actions which the makers as members of a discourse community target to accomplish, and to provide the means for the makers to relate to the viewers by influencing the attitude, belief, and behavior of the latter.

A typical sales letter, according to Bhatia [15], has its main function as being persuasive in order to elicit a specific response from its viewers. To achieve this ultimate goal, the letter should be able to capture a viewer's attention, to offer an appraisal of the product or service in relation to the viewer's needs and interests, to initiate business relations, and to encourage further communication. Accordingly, Bhatia [15] illustrates the discoursal structure of a printed sales letter in seven moves: 1) establishing credentials; 2) introducing the offer; 3) offering incentives; 4) enclosing documents; 5) soliciting response; 6) using pressure tactics; and 7) ending politely. The move of introducing the offer is further realized in three steps, namely 2a) offering the product or service; 2b) essential detailing of the offer; and 2c) indicating value of the offer.

\section{The Corpus}

In order to develop a representative corpus for data analysis in this study, attention has been paid to ensure that the letters are collected from people of as wide a spread as possible. The criteria for identifying potential recipients of sales letters, as outlined in Table $\mathbf{1}$ below, are derived from a correlation of four variables: age group, gender, educational background, and occupation. The selection of these four variables is based on two assumptions. First, in order to increase business profitability, products and services are generally designed to fit the needs and demands of different consumer segments. Second, boundaries of consumer segments can be set by making correlation among the levels under each of the four variables.

The levels of the four variables demand either half or one-third of the total sample population. Based on the above table, 36 categories of recipients are possible. The recipients were identified through personal contacts. They were asked to forward to the author of this article any sales letters (prints or emails) in Chinese and/or English that they received over a six-month period; the letters could come from Hong Kong, mainland China, or overseas, and, could aim at selling or promoting any brands, products, or services. The six-month period for data collection covered various major festivals in Hong Kong, including the Mid-Autumn Festival in September, Christmas in December, New Year in January, and Lunar New Year and Valentine's Day in February. As expected, the data collected is rich in variety.

Out of a total of 10,972 sales letters collected, 160 texts (80 prints and 80 emails) were randomly selected for a qualitative analysis. The selected texts cover a wide range of products and services, including magazines, computers, cosmetics, medicines, insurance, fashions, financial services, 
Table 1. Variables of the Sample Population for Data Collection

\begin{tabular}{|c|l|c|}
\hline Variables & Levels & Distribution of Samples \\
\hline \hline Age group & $1 . \quad 15$ to 25 years old & $1 / 3$ \\
& $2 . \quad 26$ to 40 years old & $1 / 3$ \\
& $3 . \quad 41$ years old or above & $1 / 3$ \\
\hline Gender & $1 . \quad$ Male & $1 / 2$ \\
& 2. Female & $1 / 2$ \\
\hline Education & $1 . \quad$ Secondary level or below & $1 / 2$ \\
& 2. Tertiary level or above & $1 / 2$ \\
\hline Occupation & $1 . \quad$ Management or professional \\
& 2. Mid-level or skilled worker & $1 / 3$ \\
& $3 . \quad$ Junior or unskilled worker & $1 / 3$ \\
\end{tabular}

and so on, and also come from a wide spectrum of organizations, such as British Royal Mint, HSBC, Lane Crawford, Manulife Insurance, McAfee, and so on. Since the messageencoding strategy and method of a sales letter might be influenced by the style and preference of its makers, it was decided that each letter should come from a different company as far as possible in order to help minimize the effect of makers' style on the validity of the results.

\section{The Specialist Informants}

In the process of data analysis, it had been considered whether the descriptions of move types found in studies of similar contexts were applicable to the data of this study and whether modifications of the move types would be necessary. It could, however, be dangerous to claim and justify the limited applicability of previous move schemes based solely on the judgment of one analyst. There might exist, for example, personal misinterpretation of text or inappropriate application of the schemes. Indeed, Swales [19] did admit in his attempt to devise a move pattern for the introduction section of 48 research articles that he was open to being charged for having the result of his work being a "reflection of his perceptual predispositions". He supported himself by a claim that "the charge is likely to be less serious in a genre-specific 'bottom-up' applied study than in 'top-down' discourse analysis aimed at developing our understanding of features common to all texts". He, however, in one of his later publications, acknowledged the necessity of consulting specialist informants in move analysis, and suggested, "extra-textual excursions provide a valuable framework for situating particular texts with their environments" [20]. To avoid the potential charge of achieving results that were based on personal judgments [21], the author of this article found it crucial to seek help from specialist informants to review the move scheme she put forward and at a later stage, to test the validity of the data analysis; five specialist informants who on average had been working in the field of promotional writing and editing for ten years were consulted for such purposes.

The first specialist informant is a male Chinese marketing director of an advertising agency in Hong Kong. He is a graduate from a university in the United States, and has 12 years of consultancy experience helping his local and international clients to sell and promote different products and services in Hong Kong. He was invited to share his understanding of the strategies in sales promotion communication typical in the Hong Kong context. The second specialist informant is a male Chinese copywriter. He got his arts degree in communication and linguistics from a Hong Kong university, and has 13 years of full-time and freelance experience in writing and translating business communication texts for different companies. His expertise in copywriting covers advertisements, press releases, corporate communications materials, sales promotion letters, and more. His help was sought in providing professional knowledge about the process of writing sales promotion letters in Chinese and of translating business texts from English into Chinese. The third informant is a male British copywriter and managing director of a consultancy firm on all kinds of copywriting. He is holder of an arts degree in Chinese language from the University of London, and has 30 years of experience working in the field of writing marketing communication texts for different companies in London, Hong Kong, and mainland China. His assistance was needed in sharing professional knowledge about the process of writing sales promotion letters in English and in Chinese-English translation. The fourth specialist informant is a male Chinese art director. $\mathrm{He}$ is a high-school graduate and in 2001, established his own creative services company. Over the years, he has been helping his clients and his own company to produce online and printed sales promotion letters. Depending on requirements from clients, he might be responsible for drafting the letters himself or producing interactive online letters based on content provided by clients. His productions were mainly presented in English. He was asked to share his professional experience on the production of sales promotion letters, especially the online ones. The fifth specialist informant is a male Chinese instructor in the Department of Chinese, Translation and Linguistics at City University of Hong Kong. He holds a master's degree in linguistics, and has over 10 years of experience coordinating and teaching courses on applied linguistics and translation. One of his major research interests is to investigate the impact of cultural elements on the translation of sales promotion texts in Chinese and in English.

\section{RESULTS AND DISCUSSION: THE MOVE SCHEME}

It is assumed here that if a genre is the result of constant and cumulative selections from structural choices governed 
by the communicative purposes, then it should be possible to quantify these selections. Sales letters in the corpus were found to share mutually exclusive moves and steps according to the following move scheme (see Table 2) proposed by the author of this article and validated by the five specialist informants mentioned above.
In association with the move scheme, a move is identified in a sales letter as a genre-specific text in terms of four criteria: (1) the propositional content of the letter; (2) the relationship between the letter and the co-text; (3) the context of situation in which the letter emerges; and (4) the linguistic indicators typical of a particular move type in the letter. Taken as a communicative event, a move can be real-

Table 2. A Move Scheme for Analyzing Sales Letters and Emails

\begin{tabular}{|c|c|c|c|}
\hline \multicolumn{2}{|l|}{ Moves } & \multicolumn{2}{|l|}{ Steps } \\
\hline Move A & Setting the scene & $\begin{array}{l}\text { Step A1 } \\
\text { Step A2 } \\
\text { Step A3 } \\
\text { Step A4 } \\
\text { Step A5 }\end{array}$ & $\begin{array}{l}\text { Relating to a social issue } \\
\text { Relating to culture } \\
\text { Relating to the market situation } \\
\text { Relating to the viewer } \\
\text { Relating to the maker/character }\end{array}$ \\
\hline Move B & Establishing credentials & $\begin{array}{l}\text { Step B1 } \\
\text { Step B2 } \\
\text { Step B3 } \\
\text { Step B4 } \\
\text { Step B5 } \\
\text { Step B6 } \\
\text { Step B7 }\end{array}$ & $\begin{array}{l}\text { Highlighting financial strengths } \\
\text { Highlighting leadership } \\
\text { Highlighting uniqueness } \\
\text { Highlighting recognition/status } \\
\text { Highlighting exclusiveness } \\
\text { Highlighting expertise } \\
\text { Highlighting track records }\end{array}$ \\
\hline Move $\mathrm{C}$ & Introducing the offer & $\begin{array}{l}\text { Step C1 } \\
\text { Step C2 } \\
\text { Step C3 } \\
\text { Step C4 } \\
\text { Step C5 } \\
\text { Step C6 } \\
\text { Step C7 } \\
\text { Step C8 } \\
\text { Step C9 } \\
\text { Step C10 } \\
\text { Step C11 } \\
\text { Step C12 }\end{array}$ & $\begin{array}{l}\text { Identifying needs } \\
\text { Stating the intention } \\
\text { Mentioning the product/service } \\
\text { Describing services/functions } \\
\text { Describing advantages } \\
\text { Describing limitations/restrictions } \\
\text { Showcasing latest developments } \\
\text { Providing details } \\
\text { Providing guidelines } \\
\text { Pointing to further information } \\
\text { Linking to/Presenting evidence } \\
\text { Offering guarantee }\end{array}$ \\
\hline Move D & Building goodwill & $\begin{array}{l}\text { Step D1 } \\
\text { Step D2 } \\
\text { Step D3 } \\
\text { Step D4 }\end{array}$ & $\begin{array}{l}\text { Projecting foresight } \\
\text { Showing commitment } \\
\text { Anticipating feedback } \\
\text { Encouraging circulation }\end{array}$ \\
\hline Move E & Offering incentives & $\begin{array}{l}\text { Step E1 } \\
\text { Step E2 } \\
\text { Step E3 } \\
\text { Step E4 }\end{array}$ & $\begin{array}{l}\text { Providing gifts/discounts } \\
\text { Providing free trials } \\
\text { Providing free tests/games } \\
\text { Providing value-adding services }\end{array}$ \\
\hline Move F & Using pressure tactics & & \\
\hline Move G & Triggering action & & \\
\hline Move $\mathrm{H}$ & Soliciting response & & \\
\hline Move I & Reinforcing the offer & & \\
\hline Move J & Building rapport & $\begin{array}{l}\text { Step J1 } \\
\text { Step J2 } \\
\text { Step J3 } \\
\text { Step J4 }\end{array}$ & $\begin{array}{l}\text { Conferring blessings } \\
\text { Expressing eager anticipation } \\
\text { Expressing gratitude/appreciation } \\
\text { Expressing apology }\end{array}$ \\
\hline
\end{tabular}


ized in one or more steps. A coding analysis of all the 160 texts was conducted by two independent coders, and intercoder reliability was calculated. Agreement between the coders was substantial with Cohen's kappa value $=0.927$.

In the following discussion, extracts will be taken from the English and Chinese sales letters to explain and illustrate each move and step. An English translated version of each Chinese extract can be found below them. A move is considered obligatory if it appears in more than 140 out of the 160 sales texts; quasi-obligatory if it appears in more than half but fewer than 139 out of the same; and optional if it appears in fewer than half of the same also.

\section{Move A Setting the Scene}

In this move, the makers put the sales proposition in context and make it sound logical and relevant to the viewers. The purpose of this move is two-fold: 1) to alert the viewers to their surrounding environment which is apt to be dynamic and evolving, and 2) to establish a viewer-maker relationship which is fundamental for an effective communication. In response to a question about the critical success factor(s) of a sales letter, all the five specialist informants mentioned in their consultations that a maker should create a feeling in the viewers right from the onset that what is going to be covered in the letter is of relevance and benefit to them.

Move A Setting the scene appears in 95 out of the 160 sales texts, indicating that this move is quasi-obligatory. The move, which sets the contour for a sales proposition, can be realized through one or more of the five steps as follows. The five informants found the classification of the steps clear, logical, and easily differentiable.

\section{Step A1 Relating to a Social Issue}

This step mentions a social issue or phenomenon, which provides justifications for introducing an offer to the viewers. In example (1), the maker reports the high number of diabetic patients in Hong Kong based on some objective information provided by an authoritative association. The thematization of the circumstantial adjunct “據國際糖尿病聯合會最新資料” [Translation: According to the latest information from the International Diabetes Federation] signals to the viewers that the social phenomenon is factual and the source is reliable. This description then leads logically to the sales proposition of a diabetic food to be introduced later in the sales letter. This step may be presented in past tense when referring to a past event or in present tense when citing some factual information.

\section{（1）據國際糖尿病聯合會最新資料, 香港的糖尿病比例全球排名第 一, 新加坡第四。}

[Translation] According to the latest information from the International Diabetes Federation, Hong Kong has the highest number of diabetic patients in the world, and Singapore ranks fourth.

\section{Step A2 Relating to Culture}

This step relates the viewers to some specific cultural elements with which they can identify. Example (2) is extracted from a letter promoting a gold medal of the year. The maker highlights the horse, a favorable animal in Chinese culture, to portray an atmosphere full of success, prosperity and joy in the Chinese Lunar New Year.

(2) The Year of the Horse is coming. Being the symbol of success and prosperity, the horse is a very popular lunar animal among the Chinese.

\section{Step A3 Relating to the Market Situation}

This step appears when a maker reminds the viewers of some market changes which a sales letter will address. In example (3), the maker draws the viewers' attention to changes in the banking industry. In general, the more changes there are in the market, the stronger will be the justifications for the sales proposition. Some explicit signals for this step include "market", "trends", "changes", "nowadays", which appear in clauses or phrases, such as "Today, $82 \%$ of the French executives see Asia as the biggest market in the world." Percentages are sometimes used to indicate a particular aspect of the market situation, as in "Prevention is better than cure!' According to a report from USA, $75 \%$ of enterprises will be closed if the IT system is not recovered within 14 days!"

(3) You may have heard about the changes that are taking place in the banking industry because of the planned deregulation of interest rates in July. I am writing to explain to you how our banking services will be affected in general.

\section{Step A4 Relating to the Viewer}

This step signifies the intention of the maker to establish a relationship between the viewer and an offer mentioned somewhere in a sales letter. By thematizating the circumstantial adjunct "By now", the maker in example (4) highlights the customer relationship established earlier, which paves the way for the introduction of further privileges and benefits later in the letter. This step is characterized by explicit signals which are mainly you-oriented, and which portray the viewer as someone unique and successful, who deserves the reward to be recommended for the sales proposition. There are also cases in which the needs and interests of the viewer are mentioned, as in examples (5) and (6).

(4) By now, you may have started to take advantage of the wide range of privileges and benefits that the American Express Card offers, such as Membership Rewards and 90-day Purchase Protection.

(5) Planning a trip for National Day? Having things stolen may be just one of the unwelcome surprises that can happen when you're traveling.

(6) Being a stamp fancier like you, this year will surely be a year of exciting and bountiful stamp collection.

\section{Step A5 Relating to the Maker/Character}

This step is another attempt to establish a viewer-maker relationship. Example (7) is extracted from a sales letter promoting Christmas cards produced by some disabled people. The maker tries to impress the viewers by describing the 
spiritual qualities of the people who are the main characters of the letter. Explicit signals of this step are those which are we-oriented or I-oriented.

(7) With a strong sense of self-reliance, spirit and determination we strive to overcome our disabilities.

\section{Move B Establishing Credentials}

To differentiate itself from the competitors, a company will establish its credentials either as a market leader or as a niche player supported by concrete evidence. It is found from the data examined in this study that Move B Establishing credentials, usually explicitly signaled by companyoriented or character-oriented descriptions, can be achieved through highlighting a company's financial strengths, leadership, uniqueness, recognition/status, exclusiveness, expertise, or track records. The move can be presented in past tense when referring to a past achievement or in present tense when describing a current strength. It is perceived by the informants as non-obligatory in the move scheme, since it might not be necessary for some renowned, wellestablished or easily recognizable brands such as IBM to establish their credentials with lengthy descriptions in their sales letters. On the other hand, it tends to be playing a more important role in sales letters issued by some new or less well-known companies which might be trying to get into the market or to increase exposure locally and globally, as confirmed by the first and second specialist informants from their experience of serving clients in mainland China. Move $B$ can be regarded as quasi-obligatory in the move scheme, since it appears in 94 out of the 160 sales texts.

\section{Step B1 Highlighting Financial Strengths}

The lexical expressions which signal this step are those related to assets, revenues, financial strengths, etc. In example (8), AIG states explicitly its total assets, against which the September 11 terrorist attacks would not cause any adverse influence on its financial structure. In fact, the maker starts the sales letter with a headline "Now the dust is settling...Let's rebuild our confidence in life!" and a subheadline "A Most Serious Human Disaster - The 911 Attacks". The stronger the impact of the attacks on the public was, the more likely a higher number of insurance claims would result. The greater the emphasis was put on how AIG could take care of the financial burden stemmed from the insurance claims, the sharper its role as a leading insurance organization could be established. Here, the financial strength of AIG is portrayed against a crisis known to the public.

(8) 由於AIG是全球最具實力的保險及金融機構之一, 資產總值超過 4,000億美元, 故事件對集團的財政影響是微不足道。

[Translation] Since AIG is a leading U.S.-based international insurance and financial services organization with total assets of over US $\$ 4,00$ billion, these terrible attacks will not adversely affect the AIG financial structure.

\section{Step B2 Highlighting Leadership}

This step is signaled by adjectives such as "ranked \#1" and "leading", as in the following example.
(9) Fraud can be remote and inaccessible. IFC is the leading event that connects organisations from around the globe. The UN Secretary General fully supports programmes that help to eradicate financial crime, and effective fraud prevention frequently depends on relationships that have been created at this event.

\section{Step B3 Highlighting Uniqueness}

This step may be explicitly signaled by expressions that describe the unique positioning of a company or of an event. As in example (10), the claim of uniqueness can be realized through making contrast with products or services provided by competitors or through pinpointing the fact that a company is the sole provider of a product or service. Explicit signals of this step include "sole / the only / no other...", "unique", "unprecedented", and "the uncommon".

(10) You simply can't lose! No publication guides you like Harvard Business School Publishing's Harvard Management Update.

\section{Step B4 Highlighting Recognition/Status}

Recognition and status are generally established through the provision of figures in the data examined in this study. By emphasizing that more than 95 percent of the schools made NEC projector their choice, the maker in example (11) tries to lead the potential customers to feel that it must be a good product worth purchasing. This move is explicitly signaled by lexical items such as "the world's most respected", "widely used", "widely recognized", "renowned", "awardwinning", and "receiving top ratings".

\section{（11）由於品質超卓及價錢優惠，現已有超過九成半學校選用NEC液 晶投影機作為多媒體教育用途。}

[Translation] Thanks to its good value and superb quality, over $95 \%$ of the schools in Hong Kong have chosen NEC projector to facilitate classroom teaching, making NEC the distinct number ONE supplier in the market.

\section{Step B5 Highlighting Exclusiveness}

This step is used when the maker wants to highlight the customer selectivity operated by a company by featuring the viewer as someone among a few of selected privileged customers to receive an offer or an invitation. The rarer the customers are being selected, the more privileged they will feel they are. The use of passive voice, such as "was selected" in example (12) implies that it is the company which decides whom to invite. By highlighting that the offer is not for everyone, the maker is indeed helping the company enhance its credentials - it is a company with expectations and requirements, and its offers are exclusive for the few selected customers. A win-win situation between the company and the viewers is eventually created.

(12) Remember, not everyone was selected for this chance to enjoy a free copy of Benchmark and receive a FREE Executive Briefcase.

\section{Step B6 Highlighting Expertise}

In this step, the maker establishes a company's credentials through highlighting its expertise and experience in the 
industry. In example (13), the maker highlights the company's long-term history in research which portrays a serious and professional image for the company and provides justification for the claim on quality guarantee. Explicit signals for this step include, for example, "specialized in", "expert", "authority", "extensive experience", "well qualified", and "world class".

\section{(13) Double A紙是泰國的領導品牌, 採用最優質的原料再加上逾} 17 年的研究, 質素最有保證。

[Translation] As the leading brand in Thailand, Double A paper is made from the highest quality raw materials with over 17 years of research. Quality is surely guaranteed.

\section{Step B7 Highlighting Track Records}

To help a company establish its credentials, the maker may highlight some track records of its achievements. Example (14) is taken from a sales letter of a design company, which showcases its strong profile in working with a renowned cosmetic brand in the market. This move was originally labeled as Highlighting past records. However, since some of the achievements are described in an ongoing manner in some letters, consensus was reached among the five specialist informants that it would be better to rename this step as Highlighting track records. Their advice was taken, and the step was renamed.

\section{（14）在早前的日子裡, 我們也成功地為一間著名日本化妝公司 “IPSA” 網站本地化。}

[Translation] Earlier on, we successfully helped a well-known Japanese cosmetic brand named "IPSA" to customize and launch its localized website in Hong Kong.

\section{Move C Introducing the Offer}

All the five specialist informants, in their consultations, described Move $C$ Introducing the offer as an obligatory move in the move scheme. They stated that viewer benefit is very often used as the key persuasive appeal in sales letters. They also mentioned that before writing a sales letter, they usually study carefully the specifications of a product or service, and sometimes try to use it themselves to get a firsthand experience. They would also gather information from the clients about the profiles of the target viewers of the letter, such as age, gender, education levels, professions, purchase habits, etc. The fifth informant further divided this knowledge of readership into two aspects, namely corporate observation and copywriter observation. A corporation or a company learns about the readership from market research and consumer purchase history, etc. A copywriter, suggested the informant, should not rely totally on information provided by a corporation. He or she should keep an eye on the dynamics of the social context by observing people's behaviors and reading magazines to stay alert of the characteristic features of different segments of readership. This kind of knowledge helps the copywriter tune in to the styles and tones of the target viewers - We speak with the same voice. Move $C$ appears in 153 out of the 160 sales texts, and thus may be regarded as an obligatory move in the move scheme. It can be realized through some combinations of 12 steps.

\section{Step C1 Identifying Needs}

This step is in use when the maker identifies needs of the viewers and shows how the offer can meet them. Some signals found in the data are conditional statements such as "Well, if you're...", and expressions such as "you need..." and "want to...?". In example (15), the maker puts "to effectively promote the implementation of multimedia in teaching" in the thematic position of the statement to explain the motive behind the need for installing a projector in each classroom.

\section{（15）要更有效地推行多媒體教學, 每個課室應各自備有投影機。}

[Translation] To effectively promote the implementation of multimedia in teaching, there is a need to equip each classroom with a projector.

\section{Step C2 Stating the Intention}

The maker states the intention of approaching the viewer in this step. It prevents the viewer from feeling that he or she is contacted out of the blue. In example (16), the maker puts the intention in explicit terms by asking a question "Why am I making you such an offer?" This step can be realized from the context of a sales proposition, and is not associated with any particular explicit signals as reflected from the data examined in this study.

(16) Why am I making you such an offer? It's simple, really. DR. DOBB'S began more than 25 years ago as a forum of shared technical information among programmers. I'm carrying on that DDJ tradition in the hope that you'll join us.

\section{Step C3 Mentioning the Product/Service}

This step serves as a door opener to the sales proposition. In example (17), it is the first time the maker mentions the Standard Chartered VISA Platinum Card in the letter. In the process of consulting the specialist informants, thought was given to whether this step could be merged with Step C4 Describing services/functions. When this issue was brought to the attention of the fourth specialist informant who has his expertise in the field of new media, he stressed the potential importance of this step to the sales emails. He explained from his experience in online sales promotion communication that a maker might simply mention the name of a product or a service in an email and then provide a hyperlink leading to further information. In this case, the maker would not give further details of the product or service in the main body of the text. The motive of doing so, according to the fourth informant, is two-fold. First, it serves to keep the text brief and short, for the convenience and comfort of reading on a computer screen. Second, it aims to lead the viewers to explore the related website or web pages which will host further information of the offer. Since the move scheme is developed for analyzing letters across the print and online media, it was decided that this step should be kept in the scheme.

(17) 為讓您足跡所到之處, 以至生活每個細節, 皆專享白金級的權 益和禮遇, 我們現誠邀您成為渣打白金VISA卡客戶, 烜赫身分 與非凡地位, 不言而喻。 
[Translation] To enable you to travel and enjoy your life platinumstyle, we would like to invite you to become our valued Standard Chartered VISA Platinum Card customer. The card will bring you a world of platinum privileges and prestigious status.

\section{Step C4 Describing Services/Functions}

This step describes services or functions an offer can provide to its users. Some of the services or functions are unique to the offers themselves and form the unique selling proposition of the sales acts. In example (18), the maker describes the customized service provided by the company. According to the second and third specialist informants, providing a detailed account of an offer would enable the viewers to make more sensible judgment on the reliability of the offer.

(18) Now You Can Have Jewelry That Will Truly Impress Everyone You Meet. You can even have custom made any piece you want. Just send a photo or drawing with the size of the stone and setting you want, and we'll send a free estimate for you to consider.

\section{Step C5 Describing Advantages}

In the step, the maker describes the kinds of advantages an offer can bring to the viewer. Explicit signals for this step are those which show how a product or service of a company outperforms that of its competitors, and those which describe the viewer benefits. Very often, modal verbs such as "can" and "will" are used in the description, as illustrated in example (19).

(19) Once you have the right plan, you can look forward to the future knowing that you are properly protected and can enjoy financial independence. It also means you will have enough money set aside for the important stages in life.

\section{Step C6 Describing Limitations/Restrictions}

This step allows the maker to describe the kinds of limitations or restrictions associated with the current offer. In example (20), the maker explains the limited usage of the freeware version, which aims to let the viewer have a taste of using the software. In case he or she wants to explore further functions of the software, he or she will need to make a purchase which is the ultimate goal of the sales proposition. In example (21), the maker provides the viewer with information about the restrictions of a purchase. According to the first and fourth informants, it is increasingly important nowadays to specify the restrictions of a purchase in a sales letter given the rising public concern of consumer rights.

(20) The freeware version does not allow you to create a new business file, but you can use the two files that come with the software.

(21) Restrictions apply. 2- or 3-year term commitment required.

\section{Step C7 Showcasing Latest Developments}

In this step, the maker showcases the latest developments of a company with respect to product or service offers, as in example (22). Explicit signals for this step include, for ex- ample, "news", "revolutionary", "breakthrough", "creation", and "brand-new series".

\section{(22) 今年秋季, 連卡佛的中環總店及時代廣場分店將加入全新系列 Burberry男女裝、鞋履及配飾產品, 並與海運大廈分店一同推出 Giorgio Armani的另一品牌 - Armani Collezioni男女服裝。}

[Translation] We are proud to announce that this autumn, the Central flagship store and the Times Square store of Lane Crawford will carry a full range of Burberry menswear, womenswear, shoes, and accessories. We will also be introducing Armani Collezioni - another label of Giorgio Armani for men and women at the above stores as well as at our Ocean Terminal store.

\section{Step C8 Providing Details}

This step, plainly informational, is used when the maker provides details of an offer, for example, by describing the content of an offer as in example (23).

$$
\begin{aligned}
& \text { The Asian Asset Management Directory provides you with } \\
& \text { the latest and most up to date contact information for the } \\
& \text { Asian fund markets. The directory contains... Markets } \\
& \text { covered include... }
\end{aligned}
$$

\section{Step C9 Providing Guidelines}

In this step, the maker provides the viewer with guidelines, mainly procedural, on how to use a product or service. In example (24), the maker provides step-by-step instruction to the viewer on how to use a software program. It is done with a hope that the viewer will feel he or she is valued and is protected from any possible troubles. This step, in turn, helps to win trust and confidence from the viewer in product usage. The explicit signals are found to occur as process verbs, such as "start", "open", and "choose".

(24) So, if you haven't found it already, here's the path:

$$
\begin{aligned}
& \text { 1. Start Dialog Strategy (Choose Start - Programs - Dialog Strategy } \\
& \text { - Dialog Strategy) } \\
& \text { 2. Open "demo.dsb" } \\
& \text { Business Navigator now appears... }
\end{aligned}
$$

\section{Step C10 Pointing to Further Information}

The maker, in this step, points the viewer to further information about an offer by providing hyperlinks to a web page as in example (25) or by enclosing related documents as in example (26). This step arises from a merger of two steps, namely Providing hyperlinks and Enclosing documents. Given that all the specialist informants perceived these two steps as basically serving the same communicative purpose, the steps are subsumed here within this Pointing to further information step, which provides umbrella coverage for all kinds of product or service information not included in the main body of a sales letter. Some explicit signals for this step include "For details:...", "attach / enclose", "browse", and "refer to".

(25) To win an opportunity to see one of these French masterpieces, come and visit www.lessaisons.com.hk and play our simple online quiz. 
(26) 我們隨函附上產品簡介, 並列出產品功能及特點以供參考。

[Translation] We now enclose a leaflet detailing the features and specifications.

\section{Step C11 Linking to/Presenting Evidence}

This step allows the maker to present qualitative or statistical evidence from third parties, namely the current users of a product or service in order to show how good and effective it is. In example (27), the maker describes how the majority of subscribers treasure every issue of the magazine. In example (28), the maker cites the commendation from a renowned person in the industry to persuade the viewer of the value of the present offer.

(27) Perhaps that's why 93\% of our subscribers never discard a single issue of DR. DOBB'S. We cover such a varied range of useful programming tools that our readers refer back to the pages of DDJ for years.

(28)
“...an extremely useful tool in the process of identifying foreign business interests in Hong Kong." Tim Davies - Asia Regional Director, Business Development, Kroll Associates

\section{Step C12 Offering Guarantee}

This step allows the maker to enhance customer confidence in a product or service by offering guarantee. In example (29), the maker does so in the format of a refund. Typical signals for this step are "guarantee" and "rest assured that...".

(29) What's more, irrespective of whether you have claimed or not, all the premiums paid will be refunded in full, guaranteed, at the end of the 7-year term.

\section{Move D Building Goodwill}

Sales and marketing communication are about promoting a brand, product, or service, and about establishing a positive relationship between a company and its target customers. Move D Building goodwill is used by makers to achieve such purposes. The fact that this move appears in fewer than half of the sales texts examined in this study (68/160) indicates it is an optional move in the move scheme. It can be realized through any of the four steps as follows.

\section{Step D1 Projecting Foresight}

To enhance goodwill of companies, the makers of some sales letters in this study are found to be projecting their companies as dynamic and sensitive to the changing environment. In example (30), the maker portrays a positive outlook for the company by emphasizing how it observes the challenge of globalization. In example (31), the maker asks the viewers to "stay tuned" for some great stuff to come. This request sets up the viewers' curiosity for something unexpected, which was described as a very effective sales strategy by the five specialist informants. This step is typically signaled by expressions such as "project" and "explore".
(30) The ACIIA members have recognized that uniform centrally-ruled exams are outdated and do not fit the true qualification requirements for the variety of the Capital Markets worldwide. ACIIA's understanding is, that the challenge of globalization can only be met successfully with partners who perceive the dimension of true globalization by respecting world-class consistent skills and knowledge as well as the values and quality of regional expertise.

\section{（31） SUNDAY新花款陸續有來, 密切留意呀!}

[Translation] Stay tuned for more great stuff coming your way from SUNDAY!

\section{Step D2 Showing Commitment}

We admire people who are committed to their job and who are willing to contribute to society. In example (32), the maker uses future tense and adverbs "will persistently and meticulously enforce" to describe the serious commitment of the company in monitoring credits. The stress on completing the job within a timeframe agreed with clients serves to indicate the respect the company pays to its clients. This expression helps to win trust from the viewers. In example (33), the maker describes how part of the membership fee will be used in research projects and education, which will eventually benefit the society at large. Indeed, the five specialist informants explained in their consultations the importance of "packaging" a sales proposition. Doing too much hard selling may do more harm than good to a product or service. The makers need to point out the benefit of a product or service to the viewers and to the society. This step is explicitly signaled by expressions such as "strive to", "enthusiasm", and "persistence".

(32) Asia Credit Monitors will persistently and meticulously enforces its collection maneuvers and tactics, within a timeframe agreed with clients.

(33) You can take pride in knowing that a portion of your fee will help the Society's ongoing worldwide research, exploration, and educational projects.

\section{Step D3 Anticipating Feedback}

In this step, the maker sets up a feedback mechanism so that the viewers will have a channel to convey their opinions and comments to the company, for example, with the use of expressions “希望 / hope”, “提供 / provide”, and “寶貴意見 / valuable comments” in example (34).

\section{（34）希望閣下撥冗泣臨參觀, 提供寶貴意見, 使「電子圖書館」 的發展更配合教育需要。}

[Translation] We sincerely hope that you can pay a visit to the event and provide your valuable comments, which will help us develop more effectively the "Digital Library" in accordance with educational needs.

\section{Step D4 Encouraging Circulation}

Taking advantage of the Internet, the makers of sales emails can more readily build up a bigger sales network and promote goodwill for companies through viral marketing as 
in example (35). Explicit signals of this step include, for example, "forward" and "transfer".

(35) Please feel free to forward this e-mail to everyone in your company or organization that might also be interested.

\section{Move E Offering Incentives}

Identifying this move is relatively easy and straightforward. Various incentives such as gifts, discounts, free trials, and value-adding services are found to be in use in the sales letters to tempt customers to purchase a product or service. The first and fourth specialist informants suggested that it would be better to do a differentiation among the incentives since sales letters across the print and the online media might show preference in employing particular kinds of incentives. In other words, differentiating the incentives into different steps might help to identify characteristics of the sales genre across the two media. The appearance of Move $E$ in fewer than half of the sales texts examined in this study $(65 / 160)$ indicates that it is an optional move in the move scheme. The four steps of the move are presented below.

\section{Step E1 Providing Gifts/Discounts}

Very often, this step is signaled by lexical items such as "free", "savings off", "benefit", "gift", "waive", and "complimentary". Provided a certain condition is fulfilled, the customer will be entitled to the benefits, as in example (36).

(36) We find that most departments need more than one copy of this essential reference tool: with this in mind you will receive a special $15 \%$ discount on orders of 3 or more copies.

\section{Step E2 Providing Free Trials}

This step resembles Step E1 by offering something free to the viewers. Instead of providing gifts or discounts, this step features the offer of free trials. In example (37), it is said that the viewer will be offered a free copy of Benchmark magazine if he or she commits to the subscription. This step is different from Step E1 in two major aspects. First, the incentive offered is the product or service itself. Emphasis is put on the experiential needs of the customers. Second, the incentive is bound by constraints such as that of time in example (38). Some explicit signals of this step include "free trial", "try", and "risk-free trial subscription".

(37) Enjoy Benchmark Absolutely Free!...You'll benefit from our 100\% RISK-FREE offer which entitles YOU to enjoy a free copy of Benchmark.

（38）由即日起, 您只須攜同此信到臨我們任何分行, 即可免費試用 卓越理財至9月30日止。

[Translation] Enjoy a free trial from now until 30 September by simply bringing along this letter to any of our branches for an upgrade to HSBC Premier.

\section{Step E3 Providing Free Tests/Games}

As predicted by the fourth specialist informant, this step is found to appear only in the sales emails examined in this study. The maker encourages the viewer to run a test or a game on the computer with a hope to achieve various purposes. First, the company can learn about data generated from the online test or game run on a viewer's computer. As exemplified in (39), the data will be analyzed and feedback will be given to the viewer. Second, a viewer will get information and entertainment. In example (40), the viewer is invited to participate in a network challenge game. The use of the lexical items "survive" and "all three levels" indicates to the viewer that this game is going to be exciting and challenging. It helps to stimulate the viewer's curiosity. Through this step of providing free tests or games, the makers invite the viewers to explore something they may not be aware of before. This step is signaled by lexical items such as "download" and "entertain".

(39) Did you ever backup your data? Are you sure you are well prepared for a disaster? Simply take a minute to go through the test. Our consultation will analyze your current situation and feedback you a recommendation proposal soon.

(40) Can you survive the Network Challenge Game?

Play our Network Challenge Game now by visiting...

\section{Step E4 Providing Value-Adding Services}

This step occurs when the maker provides the viewer with some value-adding services such as tips for using a software product as in example (41) and after-sales maintenance as in example (42). The first four specialist informants stated that customers nowadays care about what else a company can provide to them in a purchase.

\section{(41) DO YOU WANT MORE TIPS?}

We have prepared a short series of small "lesson" --- one for each day -- which will guide you through the essentials of Dialog Strategy.

（42）加上本公司提供完善的售後服務, 使用指導, 保養維修, 務使 閣下所選購的產品達至良好的效果。

[Translation] In addition, our company provides comprehensive after-sales service, instructions for users, and maintenance. We strive to make sure the product you bought will work out the best effect for you.

\section{Move F Using Pressure Tactics}

In this move, the maker attempts to push the viewers to take immediate action of purchase. The most commonly used pressure tactics include emphasizing a deadline as in example (43), and highlighting scarcity or limits in offers as in example (44). Explicit signals of this move include "limited", "rare", "starts now till...", "expires at ...", "hurry now", "first-come-first-served", and "last chance". Move $F$ only appears in 24 out of the 160 sales texts examined in this study. Thus, it can be regarded as an optional move in the move scheme.

(43) The world's leading summit on financial fraud prevention is just six weeks away. As registrations are closing shortly I was concerned that my earlier letter did not reach you.

(44) Business opportunities in this event are tremendous and precious. However, vacancies, on the other hand, are extremely limited. 


\section{Move G Triggering Action}

The maker attempts to trigger, through this move, immediate action from the viewers to commit to a purchase. Explicit signals for this move are mainly action-oriented and associated with immediacy, such as "order today", "subscribe now", and "click here" as in example (45). Move G appears in 90 out of the 160 sales texts examined in this study, and thus may be regarded as a quasi-obligatory move in the move scheme.

(45) If you haven't registered for the "iCAN auction bid", please click here!

\section{Move H Soliciting Response}

In this move, the maker solicits response from the viewer by providing information or channel for further contact and enquiries. This Move H Soliciting response is different from Step D3 Anticipating feedback in that the viewer is prompted to seek further information about an offer from the company in the former while he or she is encouraged to provide comments or to express opinions on an offer or on a company's service in the latter. It is also different from Move G Triggering action in that the viewer is invited to move forward the company-customer communication in the former while he or she is urged to commit to a purchase in the latter. Move $H$ is explicitly signaled by "For more information...please call..." in example (46). It, appearing in fewer than half of the sales texts examined in this study (57/160), can be regarded as an optional move in the move scheme.

(46) For more information on "BuyingChannels - China Edition", please call our sales representatives at (852) 81007553 or fill in the form below \& reply to us.

\section{Move I Reinforcing the Offer}

Move I Reinforcing the offer serves as a reminder to recapitulate the key attractions or benefits mentioned in the main body of a sales letter. In most cases, this move starts with an indicator “備註 / P.S." as in example (47). To highlight the reminding function, this move sometimes makes use of expressions such as "don't forget..." and "remember...". It is found from the data examined in this study that this move does not necessarily appear in a postscript position, that is to come after the sender's signature. For instance, example (48) appears as the last paragraph of the sales letter, and serves to remind the viewer once again about the strength of the service. This move is therefore labeled as Reinforcing the offer instead of Adding a postscript to reflect this flexibility in positioning. Move I only appears in 30 out of the 160 sales texts examined in this study, and thus can be regarded as an optional move in the move scheme.

(47) P.S. Don't forget, when you join today you'll receive our FREE WORLD MAP as an added benefit of your paid membership.

（48）時下能為客戶著想而有一條龍計劃安排的公司, 除DYNEGY ASIA外, 可說絕無僅有, 而此項服務亦著實能對貴公司業務有 莫大幫助, 何不考慮一試呢?

[Translation] Besides Dynegy Asia, you can hardly find a company which can provide you with a one-stop service to boost your business performance. Why not give it a try?

\section{Move J Building Rapport}

This move serves to create a heart-warming note of thanks and good wishes. It is found in the data examined in this study that this move does not necessarily appear toward the end of a sales letter. Instead of following Bhatia's move scheme to label it as Ending politely [15], a new label Move $J$ Building rapport is given to this move. Move $J$ appears in fewer than half of the 160 sales texts examined in this study (57/160), indicating its optional nature in the move scheme. It can be realized through any of the four steps as follows.

\section{Step J1 Conferring Blessings}

In this step, the maker confers blessings on the viewer for prosperity, good luck, good health, and happiness, as in example (49).

\section{(49) Wishing you a prosperous year in investment!}

\section{Step J2 Expressing Eager Anticipation}

After introducing an offer, the maker wraps up a sales proposition with a forward-looking statement in anticipation for further communication, as in example (50).

(50) Meanwhile, I look forward to welcoming you into the Society and sending you your magazines and personalized Membership Certificate.

\section{Step J3 Expressing Gratitude/Appreciation}

This step serves to express gratitude or appreciation to the viewer for his or her support in using a product or service. Common explicit signals of this step are "sincere thanks" and "gratitude", as in example (51).

(51) Thank you for your continuing support of the Society.

\section{Step J4 Expressing Apology}

This step serves to express apology to the viewer. Example (52) is extracted from a sales letter from the Fortune Magazine. Since the company has not received any subscription order from the viewer, the maker starts the letter with "We Are Deeply Sorry". The maker's expressed disappointment of not hearing from the viewer opens the dialogue to urge the viewer to give the company one last chance to serve him or her. This step is explicitly signaled by expressions such as "apology", "sorry", and "forgive".

We Are Deeply Sorry.

\section{CONCLUSION}

In this article, a sales letter is taken as a "communicative vehicle" [5] that opens up a world of business opportunities so that the "common goals" [5] of the business community, winning renown and generating profit, can be attained. It is the communicative purpose of exchanging goods, services and information, the social function of informing and persuading, and the form of transmission that allow a sales letter to be recognized by both makers and viewers as a genre distinct from other modes of communication found within the business community. A major implication of this study is 
that it illustrates the importance of understanding a text in relation to the context of situation from which the text emerges. First, this study grounds the discussion of sales promotion communication as social processes and schematic structures through the conduct of a real-life corpus analysis instead of the provision of some subjective evaluations of one or a few texts. Second, it has required assistance from members of the discourse community, namely five specialist informants to share their experience working in the field of sales promotion communication and to validate the move scheme proposed by the author of this article. The move scheme could form part of the learning materials for any courses or textbooks on the writing of sales promotion discourse. Future research could look at how the move scheme can be applicable to research across different languages and across different contexts.

\section{REFERENCES}

[1] Dudley-Evans T, Ed. Introduction. Genre Analysis and E.S.P. ELR J 1987; 1: 1-9.

[2] Purves AC. Introduction. In: Purves AC, Ed. Writing across languages and cultures: issues in contrastive rhetoric. Newbury Park: Sage Publications 1988.

[3] Bhatia VK. Worlds of written discourse: a genre-based view. London; New York: Continuum 2004

[4] Kress G. Genre in a social theory of language. In: Reid I, Ed. The place of genre in learning: current debates. Victoria: Deakin University Press 1987.

[5] Swales J. Genre analysis: English in academic and research settings. Cambridge: Cambridge University Press 1990.

[6] Bazerman C. Shaping written knowledge: the genre and activity of the experimental article in science. Wisconsin: University of Winconsin 1988.
[7] Martin J. English text: System and structure. Philadelphia: John Benjamins Publishing Company 1992.

[8] Holmes R. Genre analysis and the social sciences: an investigation of the structure of research article discussion sections in three disciplines. Engl Specif Purposes 1997; 16: 321-37.

[9] Mauranen A. Cultural differences in academic rhetoric: A textlinguistic study. Frankfurt am Main; New York: Peter Lang 1993.

[10] Vergaro C. Discourse strategy of Italian and English sales promotion letters. Engl Specif Purposes 2004; 23(2): 181-207.

[11] Guffey ME. Essentials of business communication. 5th edn. Cincinnati, Ohio: South-Western College Publishing 2001.

[12] Kramer M. Business communication in context. Upper Saddle River, New Jersey: Prentice Hall 2001.

[13] Thill JV, Bovée CL. Excellence in business communication. 5th edn. Upper Saddle River, New Jersey: Prentice Hall 2002.

[14] Devitt AJ. Generalizing about genre: new conceptions of an old concept. Coll Compos Commun 1993; 44: 573-86.

[15] Bhatia VK. Analysing genre: Language use in professional settings. London: Longman 1993.

[16] Mauranen A. Cultural differences in academic rhetoric: a textlinguistic study. Ph.D. [Dissertation]. Birmingham: University of Birmingham 1992.

[17] Upton T, Connor U. Using computerized corpus analysis to investigate the textlinguistic discourse moves of a genre. Engl Specif Purposes 2001; 20: 313-29.

[18] Bhatia VK. Analysing genre: some conceptual issues. In: Hewings $\mathrm{M}$, Ed. Academic writing in context: implications and applications, Birmingham, UK: University of Birmingham Press 2001.

[19] Swales J. Aspects of article introductions. Birmingham, UK: Language Studies Unit, University of Aston 1981.

[20] Swales J. Genre and engagement. Revue Belge de Philologie et d'Histoire 1993; 71: 687-98

[21] Crookes G. Towards a validated analysis of scientific text structure. Appl Linguist 1986; 7: 57-70. 